\title{
Participatory praxis for community food security education
}

Kim Niewolny ${ }^{a *}$
Virginia Tech

Michelle S. Schroeder-Moreno ${ }^{\mathrm{b}}$

North Carolina State University

Garland Mason ${ }^{a}$

Virginia Tech

\author{
Amanda McWhirt ${ }^{\mathrm{c}}$ \\ University of Arkansas
}

Susan Clark ${ }^{\mathrm{d}}$

Virginia Tech

Submitted May 7, 2017 / Revised August 8, 2017 / Accepted September 25, 2017 / Published online

December 15, 2017

Citation: Niewolny, K., Schroeder-Moreno, M. S., Mason, G., McWhirt, A., \& Clark, S. (2017).

Participatory praxis for community food security education. Journal of Agriculture, Food Systems, and

Community Development. Advance online publication. http://dx.doi.org/10.5304/jafscd.2017.074.009

Copyright (C) 2017 by New Leaf Associates, Inc.

\begin{abstract}
Community food security (CFS) has a robust history as a social movement addressing the politics and practice of food access and availability. While CFS advocacy and policy activity are closely connected to grassroots efforts, the academic community has supported CFS goals in a number of ways. CFS intersects with similar food movements, such as food sovereignty, emphasizing
\end{abstract}

a Department of Agricultural, Leadership, \& Community Education, Virginia Tech; Blacksburg, VA 24601 USA.

${ }^{b}$ Department of Crop and Soil Sciences, North Carolina State University, 2406 Williams Hall, Raleigh, NC 27695 USA; +1919-513-0085; michelle schroeder@,ncsu.edu

c Department of Horticulture, University of Arkansas, $2301 \mathrm{~S}$. University Ave, Little Rock, AR 72204 USA; +1-501-671-

2229; amcwhirt@,uaex.edu

d Department of Horticulture, Virginia Tech; 401-F Saunders Hall; Blacksburg, VA 24061 USA; +1-540-231-8768; sfclark@,vt.edu a social justice agenda for achieving democratic social change in the food system. In our paper, we illustrate the teaching of CFS in higher education at the graduate level where masters, professional, and doctoral students seek programmatic and community-based research experiences rooted in the goals of food justice, health equity, and ecological sustainability. Drawing upon a participatory education and critical pedagogy philosophy, we describe our approach and outcomes in developing a graduate course centered on CFS with two institutions and stakeholder participation in

* Corresponding author: Kim Niewolny, Department of Agricultural, Leadership, \& Community Education, Virginia Tech; 282 Litton-Reaves Hall; Blacksburg, VA 24601 USA; +1-540-231-5784; niewolny@,vt.edu

\section{Disclosure}

The Appalachian Foodshed Project was supported in part by U.S. Department of Agriculture National Institute of Food and Agriculture (NIFA)-Agriculture and Food Research Initiative (AFRI) Grant Award No. 2011-68004-30079. 
central Appalachia. An interdisciplinary approach was taken using a food justice lens, with special attention given to rurality, race, and class as issues informing CFS work in the region. We illustrate how course themes, assignments, and community engagement aims were collectively developed by students, faculty, and community practitioners through the Appalachian Foodshed Project, a regional CFS project. We focus our insights learned through several processes: developing and offering a pilot course in food systems; conducting focus groups with graduate students from two institutions; and collecting course evaluations from the final CFS course we developed. Our paper concludes with suggestions for utilizing a participatory approach-as praxis - to create new opportunities for students, faculty, and CFS practitioners to learn together for food systems change.

\section{Keywords}

Action Research; Community Food Security; Critical Pedagogy; Curriculum; Food Systems; Participatory Education

\section{Introduction and Review of the Literature} Community food security (CFS) has a robust history as a social movement addressing the politics and practice of food access and availability. Acknowledged as a space for advocacy, policy, and programming, CFS efforts have largely emerged from grassroots activity and partnerships (Anderson \& Cook, 1999; Fisher \& Gottlieb, 1995; Joseph, 1997). As a social movement, CFS intersects with similar movements, such as food sovereignty and food justice, as well as professional fields and academic disciplines including public health, community nutrition, urban and regional planning, ecology, sustainable agriculture, sustainable development, and asset-based community development (Allen, 2004, 2010; Embry, Fryman, Habib, \& Abi-Nader, 2012; Patel, 2009; Pothukuchi, 2004; Winne, 2008). In terms of an assessment approach, CFS extends beyond a focus on individual or household food security where food access, availability, and affordability issues are generally discussed in technical terms, and where solutions are addressed through procedural and behavior-based interventions. Instead, CFS empha- sizes the complexity of food system influences with the goal of developing healthy communities and capacity for socially just, economically vibrant, and environmentally sound food and farming systems embedded in local needs, people, and places (AbiNader et al., 2009). The definition of CFS proposed by Hamm and Bellows (2003), that all "community residents obtain a safe, culturally acceptable, nutritionally adequate diet through a sustainable food system that maximizes community self-reliance and social justice" (p. 37), reflects this dynamic scope and continues to inform the work of advocates, policy-makers, scholars, and practitioners. According to Abi-Nader et al. (2009), CFS is also a holistic community-building approach for assessing and improving the access and availability of healthy and culturally appropriate food for all members of a community. This focus on a community process provides us with the means to explore and enhance our communities through participatory approaches by purposefully intersecting issues of food, farm, and health (Pothukuchi, 2004).

Viewing CFS as both a concept and movement for social change provides an opportunity for community-university engagement as a strategy to address some of our most pressing food, health, and agricultural issues. According to Allen (2004) and Pothukuchi, Seidenburg, and Abi-Nader (2007), the CFS movement has provided new perspectives to ongoing challenges, created policy, and implemented new food system programs through a number of institutional partnerships and collaborations with universities, federal agencies, and community stakeholders. For Tanaka and Mooney (2010), food security may help "bring university and community members closer together to pursue public scholarship and community engagement" (p. 562). The fields of community nutrition, anthropology, sociology, critical food studies, and urban planning are just a few academic disciplines in which this engagement has taken hold in productive ways (see Barndt, 2012; Carney et al., 2012; Ibáñez-Carrasco \& Riaño-Alcalá, 2009; Julier, 2015; Levkoe \& Wakefield, 2011; Nelson \& Dodd, 2016). According to McCullum et al. (2002) and Minkler (2000), a growing number of CFS projects are the result of linking local and institu- 
tional relationships and resources in the design and implementation of food security and food system research and outreach. This "linking" approach largely falls under the umbrella of action research (Greenwood \& Levin, 2007), participatory action research (Freire, 2007; Reason \& Bradbury, 2008), community-based participatory research (Israel, Eng, Schulz, \& Parker, 2005), and communitybased research (Strand, Marullo, Cutforth, Stoecker, \& Donohue, 2003). These participatory approaches are increasingly popular in CFS-related fields with connections to participatory education and community development practices (Minkler, 2000). Although each approach illustrates different historical and disciplinary perspectives, we note a common thread across all. This involves an orientation to research based on equitable knowledge creation and power sharing among all partners to produce practical and socially just outcomes for community members. ${ }^{1}$

It is from this action research perspective we apply participatory praxis as a concept framing our CFS course. In education, praxis breaks down the unproductive notion that theory and practice are separate ideas (Carr \& Kemmis, 1986; Lather, 1991). Drawing upon Thompson and Pascal (2012), we use the concept to explain how our educational practices are performed and then reperformed to be more effective in addressing inequalities in our everyday work. ${ }^{2}$ Hence, praxis brings together critical reflection, theory, and practice, in participation with others through dialogue, to help develop a critical worldview and actionable ideas for socially just outcomes. As food system

\footnotetext{
${ }^{1}$ Following our training, we recognize that "action research" as used in this paper refers to a collaborative and changeoriented framework used to conduct research with community stakeholders in equal partnership to address issues of social justice and democratic community change (Greenwood \& Levin, 2007; Weber, 2011).

${ }^{2}$ Praxis is associated with Freire's (2007) perspective of Marxist thought where co-learning, critical reflection, and engaged dialogue are crucial to transforming unjust knowledge and realities. For Freire, participatory education and critical pedagogy lead to the construction of a critical consciousness, which is the foundational ability for learners to begin questioning the nature of her/his/their historical and social situation and the power relationships that (re)construct this reality.
}

educators, we draw upon this participatory education and critical pedagogy philosophy in the classroom to help us create new and transformative spaces in CFS graduate education. We drew upon this approach to utilize action research and participatory decision-making with faculty, students, and community stakeholders in the design and implementation of a graduate course focused on CFS. To show how we did this, and what it looked like, we next describe the growth of food systems education and its relationship to CFS, action research in the classroom, and the role community members and students play in the development of food system learning experiences.

Paralleling a growth in participatory scholarship within CFS is an upwelling of courses and curricula across various colleges and universities that intersect with CFS through programs in critical food studies, food systems, agroecology, and sustainable agriculture (Barndt, 2012; Clark, Byker, Niewolny, \& Helms, 2013; Galt, Parr, Van Soelen Kim, Beckett, Lickter, \& Ballard, 2013; Meek \& Tarlau, 2016; Niewolny et al., 2012; Parr \& Trexler, 2011). While course names, content, and aims differ, curricular experiences are increasingly focused on complex social and ecological problems as "wicked problems" (Hamm, 2009) in learning environments where students engage first-hand with food and farming issues (Parr, Trexler, Khanna, \& Battisti, 2007). In this vein, the National Research Council (2009) has encouraged institutions of higher education to develop innovative, community-university learning experiences to more readily address 21 st-century challenges, such as climate change and global food security. In the United States, several of these new courses and programs reflect the multifaceted and historical mission of land-grant universities, where aims of democratic citizenship and community service are emphasized (Jacobson et al., 2012). Sustainable agriculture programs, in particular, provide a platform for engaged curricula focusing on experiential learning, service-learning, and community-university partnerships (Niewolny et al., 2012).

We also see growth in course-based action research tied to this thread of food system education (Hofman \& Rosing, 2007; Ibáñez-Carrasco 
\& Riaño-Alcalá, 2009; Nelson \& Dodd, 2016). Course-based action research allows for participatory teaching and learning to serve as a vehicle for student, faculty, and community engagement for the purpose of understanding and addressing student-community goals. While teaching and learning aims may vary, several themes are foundational to the course-based action approach. First, course goals and activities may reflect ongoing or newly developed action research projects that a professor or faculty team are co-conducting with a community (Ibáñez-Carrasco \& Riaño-Alcalá, 2009). Second, participatory and communitystudent learning opportunities are essential in codeveloping content skills and knowledge where democratic and social justice principles are equally important as disciplinary-based content (Reardon, 1998; Strand et al., 2003). Third, students have active roles in course development and implementation to reflect the action-research principle of shared knowledge production and democratic decision-making (Strand, 2000).

While all three themes are equally central for CFS and related coursework, it is the last point that we focus on for the course described in this paper: student participation in CFS course design and implementation. While instructors may gather student feedback from course evaluations or other methods, this is typically done after much of the course has already been developed. Extensive changes to course content, learning objectives, and assessments based on student perspectives and ideas can be difficult to implement post hoc. Moreover, given the traditional division of roles for faculty and students and the usual predefined, content-driven syllabus, it is rare for faculty and students to collaborate as equal participants in the process of teaching and learning (Cooke-Sather, Bovill, \& Felten, 2014) and especially in the process of course development when community stakeholders are equally involved. When students are provided opportunities to participate actively in their learning and collaborate with faculty in teaching activities and course design, studies have demonstrated improved student motivation and problem-solving skills (Hudd, 2003), empowerment (Shafaei \& Nejati, 2012), and deeper engagement and communication leading to improved teaching and learning (Cooke-Sather, 2014).

Our CFS graduate course development process and outcomes are distinctive in a few ways. While courses that incorporate or focus entirely on CFS offer a unique platform for engaging students in food systems work, there is still an ambiguous understanding of student-centered approaches in food systems education (Galt, Clark, \& Parr, 2012; Galt et al., 2013) and the active role students and community stakeholders may play together in course design and activities. We also suggest that there is a greater focus on food systems and sustainable agriculture education with less attention given directly to the complexity and urgency of community food security and its intersection with social justice and food sovereignty movements. With this paper, we aim to help fill these gaps. What follows is a description of the development process and outcomes of a community-studentcentered graduate course in CFS that involved graduate students and faculty from two institutions, Virginia Tech and North Carolina State University and community stakeholders participating in the Appalachian Foodshed Project (AFP). Our graduate course development process was directly tied to the AFP, which was a multiyear action research project funded by a grant from the U.S. Department of Agriculture (USDA) National Institute of Food and Agriculture-Agriculture and Food Research Initiative (NIFA-AFRI) that addressed the critical issue of community food security in West Virginia and the Appalachian areas of North Carolina and Virginia through research, outreach, and education. At the heart of the AFP was the development of a regional network (or network of networks) to inspire, guide, and implement strategies and to build capacity to enhance community food security (Hamm \& Bellows, 2003). As a university-community partnership, the AFP engaged farmers, policy-makers, nonprofit organizations, community-based organizations, extension, and university institutions to build community capacity, cultural understanding, and organizational cohesion while implementing positive changes across the regional food system through graduate education, CFS assessment work, food system modeling, and network development. This included learning from and building relation- 
ships with a diversity of stakeholders related to community and economic development, health and nutrition, environmental advocacy, social justice, and food production, processing, and distribution.

In this paper, we describe the participatory process for how CFS course themes, assignments, and community engagement aims were developed by students, faculty, and community practitioners through the AFP. This includes reference to the Stories of Community Food Work in Appalachia initiative that AFP community partners and students co-developed as an example of utilizing course-based action research. Second, we share CFS course format and themes with an emphasis on findings from conducting focus groups with graduate student across two institutions. This is followed by insights from our experience teaching the culminating course and student input from evaluations of the CFS course offered in spring 2015. We conclude with suggestions and considerations for utilizing a participatory approachas praxis - to create new curricular collaborations and opportunities for students, faculty, and CFS practitioners to learn together for food systems change.

\section{Creating the Course: The Story of "Food Security and Resilient Communities"}

One of the five objectives of the AFP was to create and offer graduate-level coursework across the institutions focusing on the conceptual and programmatic approaches to understanding the complexity of community food security and food systems change. The core themes of the AFPsocial justice and social transformation-informed the focus on building capacity for cultural, ecological, and economic justice to better address concerns about food access, availability, and affordability in the Appalachian region. At the onset of the project, the university-community AFP leadership team agreed that the CFS course should be locally responsive to project activity and to student and community stakeholder needs, while also addressing broader issues from an interdisciplinary and intersectional perspective. We also decided that the CFS course should provide opportunities for graduate students to engage in CFS research with community members. We further focused on linking advanced-level student skills and interests with community needs as part of the AFP experience.

An AFP curriculum team formed in year two of the project and developed a food systems graduate course as a pilot. A faculty member of the AFP curriculum team conducted the pilot at Virginia Tech as an action research-based course with students and AFP community partners in southwest Virginia. Offered in 2013, the pilot course provided a unique opportunity to explore and assess CFS curricular goals and learning activities through group dialogue and the creation of a narrative-inquiry project with graduate students and AFP community stakeholders. Much of this work guided our next steps and the final course curriculum, which is discussed below.

In early 2014, a team of four graduate students and three faculty from Virginia Tech and North Carolina State University and several AFP community stakeholders across both states, worked together to develop the course presented in this paper. Course objectives, content, assessment, and community engagement aims took one year to develop. The "Food Security and Resilient Communities" course was finally offered in the spring of 2015 at Virginia Tech with the goal of cooffering the course at North Carolina State University.

We draw on four sources of data and insight to illustrate our participatory course process. First, we draw upon our project notes and observations taken over the span of the AFP's work, including numerous AFP team meetings with faculty, students, and community members held between 2012 and 2016. Second, we include observations and ideas gleaned throughout the earlier food systems course piloted in 2013. Third, we include findings from four focus groups conducted in 2014 with 27 graduate students across two of the three universities involved in the AFP project. Here, we used knowledge learned from the piloted food systems course to develop Institutional Review Board (IRB)-approved protocol and questions to conduct focus groups with graduate students at Virginia Tech and North Carolina State University (Appendix A). Lastly, we offer insights learned from teaching the final course based on our 
experiences and student evaluations from the 12 graduate students who participated in course work and design (Appendix B).

We share our story in three main sections. First, we show how the community played a role in our course development process. We next illustrate how graduate students were central in the creation of CFS course themes and learning activities. Finally, we describe the culminating CFS course design with key participatory and food system elements that framed it.

\section{The Participatory Process: Community Role} We embed our participatory praxis in the AFP's collaborative governance framework known as Dynamic Governance (now Circle Forward) (Buck \& Villines, 2007; Kunkler, 2017). The tristate AFP leadership team evolved over five years to include more than 10 university faculty and staff, 7 graduate students, and 12 community partners from North Carolina (NC), Virginia (VA), and West Virginia (WV). This leadership group created specific teams to address project objectives and activities. Each team, like the AFP curriculum team, brought its progress to the leadership team to discuss at a regional and/or state-specific level as needed. The community partners involved in the decision-making for the CFS course started with the AFP leadership team. As the course developed further, decisions were operationalized at the local level in VA and NC. This occurred through the earlier food systems course offered at Virginia Tech with $10 \mathrm{VA}$ partners involved in the design and implementation of a community food security assessment. All became involved in the course through their interest in building networks to better connect the experiences of people working for food systems change across Appalachian VA. During a community meeting in late 2013, community members proposed sharing stories of their individual work and life experiences to better understand and build upon them for greater regional understanding. With support of a Virginia Tech faculty member, the group agreed to colaunch a narrative project to create and share their stories to enhance regional connectivity as a practical first step. The group also agreed that the course could serve as the backdrop for the community partners to collaborate with the university to co-implement this narrative effort, which was titled Stories of Community Food Work in Appalachia (Niewolny, 2016). These stories became an informal, intimate space for these and other community members to build understanding and empathy about the everyday experiences of people working to make a positive change in the regional food system. The stories highlight individual and collective voices and describe projects, such as the creation of a CSA-food pantry partnership, structures for community organizing, the formation of new food hubs, youth and senior advocacy for food access, and the impact of school and community gardens (Niewolny \& D'AdamoDamery, 2016).

The pilot (2013) and final (2015) courses became the vehicles for the making and sharing of the community food work stories; thus it was from this perspective that AFP community partners actively provided their input and presence in creating and teaching of CFS course. Specifically, this narrative-inquiry research provided an important foundation for campus and community discussions about CFS and the role graduate education can play in building capacity for a healthy food system in the region. We followed action research principles (Greenwood \& Levin, 2007), with AFP community practitioners and graduate students taking the course to create an IRB-approved protocol for the storytelling process and questions that informed the narrative-based interview. This approach allowed the community member to tell their ${ }^{3}$ own stories through a series of mutually agreed upon "prompting" questions to emphasize their worldviews. Following our IRB process, each narrative was consented to, audio-recorded, transcribed, re-transcribed with editing, and configured as a public and digital narrative through a coreading and framing process with the interviewers (graduate students) and storytellers (community partners). As a culminating course assignment, graduate students were charged with conducting, transcribing, and co-editing the interviews and with

\footnotetext{
3 "They" and "their" are used as gender-neutral pronouns throughout the paper.
} 
providing critical reflection on what they had learned from the story and the story-making process. Seven narratives were co-developed in the spring of 2013. In 2015, 12 additional stories were co-created through the final CFS course using a similar action research process with AFP partners and graduate students.

\section{The Participatory Process: Graduate Student Focus Groups}

Graduate students played a significant role in the design of the CFS course. Drawing upon the success of the piloted action research-based course, the AFP curriculum team sought to reach out to a greater and more diverse student audience from Virginia Tech and North Carolina State University to explore the possibility of creating a shared and interdisciplinary graduate course to offer at both universities. With the leadership of four graduate students involved in the AFP project, one of whom took the pilot course in 2013, and three AFP faculty (Virginia Tech, $n=2$; and North Carolina State University, $n=1$ ), the process of developing an IRB-approved protocol to conduct four focus group sessions began. Our goal was to recruit graduate students from both universities to create an interdisciplinary pool for the focus group sessions. These focus groups took place in April 2014 with three AFP faculty (Virginia Tech, $n=2$; and North Carolina State University, $n=1$ ) at both institutions. With informed consent from student participants, we audio-recorded sessions and transcribed them verbatim. The AFP graduate students served as the primary facilitators for each focus group session. During the transcription process, we replaced all identifying names with pseudonyms.

A total of 27 graduate students participated in the focus group sessions with 16 students at Virginia Tech and 11 at North Carolina State University composed of 17 self-identified females and 10 males. Participating graduate students came from diverse fields and disciplines (e.g., regional planning, sociology, natural resources, soil science, and education) across seven departments represented in three colleges across both universities. While many students voluntarily shared that they were U.S. citizens interested in domestic food security issues, several students either identified as international students or explicitly stated interest in studying some aspect of global food security.

We followed a descriptive qualitative design to guide the analysis of the transcripts for course content and process themes (Creswell, 2009). All transcripts were imported into ATLAS.ti to apply line-by-line coding; we identified themes and codes based on the prompting questions (Muhr, 2004). Additional codes were added based on notes the researchers took during the focus groups. One Virginia Tech researcher coded the Virginia Tech transcripts, and one North Carolina State University researcher coded North Carolina State University transcripts. The Virginia Tech researcher then reviewed the North Carolina State University transcripts and recoded sections to ensure intercoder agreement. We coded the data line-by-line to explore (1) how students understood and defined food security and food system issues; (2) personal and professional aims and motivations to study and engage with food security topics; and (3) course activity and assessment preferences to address learning goals.

Overall, our focus group data resulted in several overarching themes used to help frame the content and approach of the CFS course. These themes include a focus on students' preferences to explore or incorporate (1) a politicized understanding of food security as CFS; (2) interdisciplinary and community engagement perspectives of CFS work; and (3) personal experience and positionality in the food system. Students also mentioned their interest in exploring theoretical, programmatic, and policy approaches from both domestic and international viewpoints and literature. Together, these themes highlight students' professional and personal knowledge and learning goals.

\section{Framing Food Security as CFS}

First, the data revealed students' perceived knowledge of food security definitions and topic areas largely within the discourse of CFS. We intentionally did not provide students with a definition of food security or CFS at the onset of the focus group sessions. We asked students to provide a definition and use language they were familiar with to help frame food security discourse 
from their perspectives. Our goal was to learn how students intersect with its many meanings, disciplinary influences, and issues. "Food security," "community food security," and "food sovereignty" were terms commonly applied in the sessions, yet meanings varied as students discussed the scale, scope, and role of politics in healthy food access, availability, and affordability issues. For example, this student draws upon the commonly held "consumption vs. production" perception of food security in her definition:

My definition focuses more heavily on consumption instead of production. Being free from worry is a big central component of food security. Like not worrying about the food that you do have is going to make you unhealthy, or not worrying that you aren't going to have enough money for it. Or just not worry that there is not going to be any regardless of how much it is. If a community was food secure you would not have much expression of that worry at the community level, like you wouldn't have a lot of policy measures in play, like SNAP, or political responses to worry about...

Many students were familiar with the politics of the food system and how power influences food production, distribution, access, and wasteimpacting food security at the household, community, and transnational levels. This was often communicated through student concerns for social justice and health equity. For instance, a human rights aspect to food security was apparent for this student: "Food security means every single person has the same access to food because that's what they're entitled to as a human being. So regardless of age, class, gender, we're all people. We all have the same rights, and food is one of those rights."

Students also tied their politicized understanding of food security to economic structure and frameworks, such as neoliberalism, and movement responses to it, such as food sovereignty:

To me, it has to do with the food system's structural capacity to keep everybody happy and healthy and living a dignified existence.
So it really does have to do with the economic system, the larger economic system, the larger political structures, you know. Having access to the ability to produce food in a food sovereign world, rather than just given the access to this large central organization that's gonna provide food for me. It just has to do with having a say about how your food system is governed... as well as just the ability to acquire food.

The focus groups also allowed the AFP curriculum team to better understand students' motivation for taking a CFS course within the context of their own educational and career goals. These motivations were professional and personal in nature and include such reasons as students seeking food security-related policy, agroecological and systems-thinking frameworks related to food security, and programmatic tools to address structural inequalities impacting communities to achieve socially just and healthy food access. This last point is suggested by one student in defining what "community food security" means to them and why it is important to study:

...There are a lot of social and structural barriers to building community food security.... I would like to know how are people overcoming these barriers. A lot of marginalized populations don't have the capacity to address them. They don't have enough power to even start.

Another student articulates the professional significance of taking a course about food security, as an economist, and how it relates to the economic structures of the food system:

I tend to think in terms of minimizing the impacts of potential market disturbances so when trade routes change, or there's economic instability. I would like to minimize the impacts on a community of those particular disturbances whether they be economic or socio-political.

Together, we characterized their meanings, 
priority topics, and motivations for learning about food security that reflects Hamm and Bellows' (2003) definition of community food security. Food sovereignty and household food security discourses emerged as well, indicating their significance to the course. The following subthemes thus emerged as a list of interdisciplinary topics to frame the first draft of the CFS syllabus:

- Cooperate control of the food system and health equity impacts

- Social justice and food justice

- Food security discourses and policy (e.g., domestic and international perspectives)

- Self-sufficiency, resiliency, and sovereignty

- Agriculture and sustainable food production

\section{Interdisciplinary and Community Engagement Perspectives}

The focus group findings further illustrate students' desire for interdisciplinary perspectives and learning collaborations with peers, and their interest in learning from and directly with community practitioners through experiential learning opportunities. Students stated that they were interested in "getting a more realistic perspective" (as opposed to idealistic) and "integrating real world applications" where possible. While not all students explicitly voiced this opinion, a theme that emerged was to break out of traditional classroom models and approaches for this CFS course. This included focusing on such ideas as political advocacy and grant-writing to "fund solutions" to a food security-related problem. In this vein, smaller discussion groups or breakout sessions were preferred to best "explore the work that is being done, what is working, and what isn't."

Views about community engagement were also central to the discussion. Three of the four focus groups strongly agreed that it was important to directly engage with the community at the local or regional level for a course about CFS. In one session, students even proposed creating a studyabroad course to explore global food security as a service-learning initiative. In the domestic sphere, however, student ideas ranged from inviting a diversity of academic speakers to "working directly with a community or municipality as a service project" and "conduct[ing] a community food security assessment to give back to the local community." Another student suggested they "start a community garden." The viewpoint about service and experiential learning opportunities is further expressed by a participant:

I really like the idea of the service component and actually taking what you learn from the class and putting it into practice. Maybe group projects or something to actually come up with something that you can actually go out into the community and physically do and make a positive impact on the community.

However, disagreement about the nature and design of these experiential and service-based learning opportunities emerged. One of the four focus group sessions raised concern about working directly with community partners through a handson or experiential learning opportunity. The reason was not based on a lack of interest. Instead, students in this one group shared their apprehension in terms of not understanding what a communitypartner relationship would entail and how that kind of course experience would affect their time to address overall graduate program obligations, including field research responsibilities. The perception was that this could be a time-demanding activity that would be difficult to incorporate into one's schedule to accomplish the engagement goals well. The majority of the participating students, however, were curious about exploring the possibilities of working with a community partner or emphasizing a community issue or project in the course, although the details of this approach were not discussed in depth. For example, the following student shared their perspective on the role of community engagement, CFS, and making an impact where possible:

I will also say, a very clear bias of my own is I think anything that happens in the university should be taken out into the community and given to the community. I don't like to do any kind of work that's just going to stay 
cloistered amongst a small number of elitists. In the work that I really have enjoyed here is when research can be taken to the community for their benefit. And that can look like a lot of different types of things.

\section{Student Food System Experiences}

Making space for students' personal and professional experiences with food security and food system work was also a central theme. Focus group participants shared a number of stories that helped explain their relationship to the issues, which helped shape our overall understanding of the ideas that drive their interest and motivations in learning about CFS. We also learned what issues were powerful catalysts for framing the specific CFS issues, such as power and privilege, class and race in the food system, and working with low-wealth communities and stakeholders in rural Appalachia. For instance, a student in one focus group shared their experience working several years in the public health sector in a large urban center. They shared how this experience was pivotal to their understanding of the daily experiences of hunger and food insecurity and the role of advocacy in providing solutions where possible:

So I'm thinking of advocacy, and part of that comes from some experience that I had when I worked in public health. I was working with clients every day who had no food in their homes.... We were working with this nonprofit that worked with people getting out of homelessness. I would go in as the public health face, and I would work with their youth on some life skills, behaviors and food and nutrition. Anyway, we, the kids and I, and another adult decided to take them to the mayor and have them tell the mayor their stories. It was amazing. He had us come back before city council, and we ended up writing letters to the governor. And a lot came out. I mean I wasn't forcing the kids into anything, this was them. People don't understand what we're dealing with. People don't understand why a kid might miss school, why they are sick, you know. So, to me, it was very powerful to see the role of advocacy.

While not all students had policy, research, or community experiences to draw upon, many of the students were able to talk about their personal stories and local contexts that they represented. This gave us some sense of what information and knowledge was important to the students, which helped identify ways to best frame challenging and critical perspectives and food production and access issues. One student illustrates this point by sharing their life experience living in Oakland, California, which was critical to their understanding of poverty, urban food insecurity, and finding socially just solutions to complicated food access problems. Here a student responds to "food deserts" as a troubling and politicized concept:

I guess I have to say something about the food deserts because of living in Oakland. I mean yeah, the concept of living in a food desert, when you think about that word, that term, it sounds horrible. There have been pilot projects trying to combat this "food desert thing" where, you know, they start an urban garden. They've actually shown that in six years a three by threeradius block around these gardens have shown a decrease in drug and crime. Even in Oakland itself, in East Oakland and West Oakland....I used to live right in the middle, gunshots all the time, like you have to hopefully own a car so you can drive to the nearest Safeway or anything because they won't open a Safeway there because it's so high in crime, it's so much drugs, so much everything else. Yeah, it obviously takes a lot of community effort to fight against it. ...So unfortunately that is something that probably will persist for a while because it's hard to fight against crime and it takes a community of people. Some of these people will go to school, some of them will stay home, some of them will be gangbangers, and some of them will do other things to come together to try to form, you know, maybe a small little farm or something, even in that little community.... I think that food 
desert thing, however horrible of a statement it is, it's very applicable and while we don't want to refer to it, you are kind of forced to based on the situations that drive the political climate.

In drawing upon critical pedagogy and participatory educational approaches, we advocate that the stories and experiences of the participant are vital to the learning process. The way students frame their relationship to food system and food security ideas is rooted in their knowledge, ideas, and realities. The cultural context provides the foundation for in-depth and critical growth. In the next section, we show how we opened that participatory space in the final design of the course.

\section{Bringing it Together: Putting Forth the CFS Course}

Our experience with the pilot course complements the focus group data and lessons learned from the larger AFP community. With graduate student leadership from the AFP curriculum team, we titled the CFS course, "Food Security \& Resilient Communities: Food Systems Theory and Practice" (FSRC). To enhance interdisciplinary learning, we created two courses to offer simultaneously at both Virginia Tech and North Carolina State University during the spring of 2015, with the intention of sharing the curriculum and opportunities for AFP faculty and community collaborations through guest speaking and course activities. The faculty leads from both universities created a shared calendar to bring the classes together virtually and in-person where possible while also allowing time for local, weekly discussions. While the course was advertised, there was not sufficient enrollment to constitute teaching the course at North Carolina State University; however, the FSRC course was offered at Virginia Tech. A total of 12 graduate students enrolled in the course from four departments across two different colleges that represented both M.S. and Ph.D. programs of study, including programs within the Departments of Agricultural and Applied Economics; Agricultural, Leadership, and Community Education; Crop and Soil Environmental Science; Public and International Affairs; and Food Science and
Technology.

The same AFP faculty member at Virginia Tech, and member of the AFP curriculum team who piloted the earlier food system course, led our FSRC course. Their interest to offer this new opportunity was elevated in collaborating with two AFP graduate students at Virginia Tech who served in a co-facilitation role. These two students were responsible for supporting classroom instruction and leadership with the AFP community throughout the semester. They did not have grading responsibilities per Graduate School policies that prohibit graduate students having access to graduate student grades. One of the students had taken the pilot course in 2013, while the other student was actively taking the new course. It is important to note that both students and the faculty member were able to draw upon their campus-community experiences in the regional AFP work, including lessons learned from conducting a community food security assessment in southwest Virginia.

We designed the syllabus using both instructor-determined and student-selected themes as a critical and interdisciplinary exploration of issues related to food security and the emerging discourse of food systems (see Appendix $C$ for the syllabus summary). Following AFP partner interest, we also made it a priority to explore the role of university-community partnerships to enhance community food security and resiliency in our region. The Stories of Community Food Work in Appalachia initiative, as a component of the AFP, provided course participants with a theoretical and practical backdrop for class discussion, narrative research and storytelling, and first-hand engagement with food and farming scholar/practitioners in our region. Lastly, we collaborated virtually with our North Carolina State University AFP faculty member in a guest-speaking capacity to honor our commitment for developing new and interdisciplinary learning possibilities.

The first half of the course focused around seven predetermined and interconnected themes that built upon one another. For the first week, drawing upon Hamm (2009) and others, we discussed the notion of food insecurity as a "wricked problem" and explored participants' understanding 
and meanings of food in/security as it relates to their personal and professional lives. This was crucial to build a sense of commonality and trust while acknowledging our differences in academic language, work contexts, and personal histories. We also covered the intersection of food and foodways as a cultural, social, and economic set of practices to provide students with a broad yet critical and shared language that resonated with our goals of creating an interdisciplinary learning space.

Our third and fourth themes were more theoretically demanding and included focusing on the connections between neoliberalism and corporate food system control coupled with food security discourses and policy. Here students delved into conceptual readings and policy documents that covered concepts and perspectives pertaining to household food security, community food security, food sovereignty, and resiliency. These paralleling themes helped us tap more deeply into course participants' historical and professional contexts related to food production and consumption agendas, underscoring their epistemological views and ontological realities about the food system itself.

For the fifth theme, we turned our attention to the complexities and possibilities of sustainable food production to address community food security and food sovereignty goals. Our collaborator in North Carolina State University took a central role this week and drew upon their agroecology research and sustainable agriculture education leadership using examples of international projects related to community food security. We also focused on key articles such as Holt-Giménez and Altieri (2013) and Holt-Giménez, Shattuck, Altieri, Herren, and Gliessman (2012) to help structure the conversation about the importance of framing food system issues and the role of science and policy in that framing. Here we emphasized the Global South and its colonial and radical histories pertaining to hunger, development, natural resources, and participatory processes to generate shared knowledge.

The six and seventh themes naturally fostered each other, spanning several weeks. Our students and AFP partners played an important role in exploring the social change goals of CFS as a social movement and the meanings and instances of food justice through the lens of the Community Food Security Coalition and the Whole Measures for Community Food Systems (Abi-Naders et al., 2009). We also drew upon Cultivating Food Justice, a text edited by Alkon and Agyeman (2011). Class activities and discussions were largely dialoguebased and highlighted the ways race, class, and gender intersect and influence food system politics, which, in turn, permeates our relationship with food, the environment, and our identity. We invited AFP partners from the Virginia Tech campus and the communities near the university to participate in these discussions and provide an organizational anchor for conversation through examples of AFP project work related to our community food security assessment taking place across the region. Through in-depth, problemposing dialogue (Freire, 2007) with student leadership, we were able to engage deeply about the ways low-wealth communities and communities of color in our region (and beyond) are historically and systemically marginalized from gaining access to healthy food, healthcare, transportation, and affordable housing. We especially focused on framing how race, class, and rural politics in the central Appalachian region influence CFS. The food justice theme not only provided a direct lens for the course but also served as a catalyst for the last half of the semester through the development and facilitation of student-led class readings and sessions.

Complete and committed participation was a core principle upon which the course operated. We used a variety of participatory methods and techniques, such as World Café and Open Space (Brown, 2002) methods to build and implement the last half of the semester as a nonhierarchical group of teachers/learners. We referred to this activity as "self-assigned readings and facilitation." This assignment required course participants to use a consent-based decision-making process to select themes and readings for the weeks in which students facilitated individual course sessions. Cofacilitation was required due to the number of course participants; students were grouped together to facilitate and select readings. As part of the activity, each group selected and disseminated theoretical or empirical readings one week before 
their facilitation took place. Students then led the class the following week in an interactive session using their selected readings. Lastly, to receive a self-assigned grade, each participant provided a written critique of his/her/their facilitation one week after using a rubric the students co-developed and to which they consented. Our expectation for all student facilitators was to be prepared to lead a critique of the readings, challenge peers to think about meaning and application, and foster interactive and civil discourse about CFS and food system issues.

The students identified four overarching CFS themes using the World Café method, including race, agriculture, and hunger, the nonprofit industrial complex; food security and asset-based community development (a programmatic approach); and theories and strategies for food systems change. Student leadership was central to this section of the course. Each week students organized role-plays, mapping exercises, critical dialogue using visual media, and discussion with article reviews. The class also produced a collective literature review to share with one another at the end of the semester.

As mentioned earlier, the community also played a pivotal role in the course. AFP partners from both the campus and community joined class sessions to talk about their role in the regional project and shared their perspectives about community food security and alternative food systems movement in the region. The course took one field trip to the City Schoolyard Garden, hosted by the executive director, Jeanette Abi-Nader. The City Schoolyard Garden is a nonprofit organization in Charlottesville that focuses on healthy and socially just food systems change with youth through garden-based experiential learning and leadership development. The graduate students took leadership in organizing a discussion about the Whole Measures for Community Food Systems (AbiNader et al., 2009) framework with Jeanette AbiNader and her City Schoolyard Garden team. Topics ranged from nonprofit organizing in the CFS movement to addressing social justice goals in the public school system. Our day concluded with a garden tour with the children at a local elementary school. This event took place in conjunction with the first-ever Virginia Farm to School
Conference. Our class served as facilitators of an Open Space session with 200 conference participants on the topic of food access and farm sustainability related to farm-to-school possibilities in Virginia. The students shared their ideas and organizing skills with producers, grassroots organizers, food nutrition directors, and governmental agency professionals. As part of the conference, we also had the opportunity to hear the First Lady of the Commonwealth of Virginia, Dorothy McAuliffe, share her vision for eliminating childhood hunger and improving access to fresh and healthy food for all Virginia residents.

Most notably, as a culminating course assignment, we continued the narrative-inquiry research project with AFP partners. This final assignment included students conducting a 90-minute narrative-based interview with a community practitioner, transcribing the interview, editing this interview for readability, analyzing the narrative by referring to course themes and literature, and sharing and co-editing the final transcript with the community partner. Here, we focused on the Whole Measures for Community Food Systems (Abi-Nader et al., 2009) as an analytical framework. As a values-based and community-oriented tool for evaluating and planning through dialogue, Whole Measures helped us see where food system change is possible. From this perspective, the narratives continued to help facilitate dialogue and a deeper understanding about how and why people from across the region, in a number of organizations and programs, including the university, are addressing the complexity of community food security. Our semester concluded with an evening "foodways" meal and reading session of the community narratives. This included a communal meal where everyone brought a food item to share that reflected how culture was expressed through their dietary habits. Students brought dishes that drew on memories of family recipes from around the Southern region and beyond, in addition to current meal options that represent trends in healthy eating and the pleasure of eating.

Student evaluations of the final course, both formal and informal, are important reflection points as we prepare to offer this course once again. While there are several measures to refer to, 
we utilized both the standard university online course evaluation as well as a complementary qualitative evaluation instrument to provide us with several indications that students positively reacted to course content and our participatory praxis approach. First, we report that our overall course evaluation for score was an average of 5.9 out of 6 points, which was above the college average. This score accompanies another high score, which includes an average of 5.3 out of 6 points measuring the level in which students' interest in the subject matter was stimulated by the course. We also received a 5.3 average score indicating the depth of understanding students gained on the subject matter as a result of the course. These scores, plus high instruction scores (6 points out of 6) illustrate that students were satisfied with their course experience.

The university online course evaluation is standard for all courses, yet is limited in what information we can glean about the student learning experience. Therefore, we created and offered a qualitative evaluation instrument that each student filled out on the last day of class through an anonymous process that the students organized and implemented. The AFP curriculum team did not have access to these evaluations until the final course grades were submitted and processed, in accordance with Graduate School policy. From these evaluations, we learned more about what the students found useful and what changes they would recommend. For example, students shared that class discussions, critical reflection statements, student-led facilitation, and narrative assignment were essential to their learning experience. One student noted how they appreciated the design of the course:

I found the class to valuable, hearing what others had to say about readings and pulling from their experiences opened my mind to so many things I had never thought of. Most classes don't allow you that type of freedom, and I feel better for having that experience. The student-led facilitation was especially good, but I found it to be most enlightening to work from the AFP narrative project, the conversations that stemmed from the planning process were wonderful.

Another student shared how they felt about the narrative assignment as their preferred learning experience:

The narrative assignment has been the most useful to me. I enjoyed having a larger assignment to dig my teeth into, and getting real life experience....I was able to develop better writing techniques and research skills while learning from someone in the field.

Also drawing upon the qualitative evaluations, we note that students referenced "agroecology" and "food justice" as their two favorite course topics and sources of readings throughout the semester. For instance, one student shared that "agroecology was a great topic because it brought in the agriculture part of food systems work." Several students also noted that these topics were new material to them, which was both welcome and yet challenging. To make this point these three students explicitly refer to food justice as the course topic that they found to be most beneficial or useful:

My favorite readings were on food justice. I learned the most from them because it had the most new information and took a critical approach to the CFS movement. I think food justice is a relevant and appropriate frame for the food security context we covered

Before I came here, I had never heard of "food security" or "social justice," and social justice issues discussed so much in a diverse group setting. The direction of the conversations were so very engaging, and I believe, eye opening for everyone. This class built a beautiful culture.

I feel like all of the readings were useful, but my favorite[s] were those readings on food sovereignty and food justice, as well as those readings which linked back to 
historical/infrastructural concerns and

policy.

In asking the students what they would recommend us doing differently to improve the course for enhanced student learning, we learned that they were very satisfied with the course as it was, knowing that in an ideal world we would have more time to cover more material. In fact, one student stated, "I think it is a perfect class. It includes everything I wanted." Another student shared that the "class was good as it was." However, the most common response (5 out of 12) was for us to incorporate more perspectives and readings that cover international or global food security issues. For example, one student wanted to "know more about how actual international trade agreements and subsides work." Another student expressed interest in "global food security and issues pertaining to developing countries."

While we recognize that the evaluations only captured a glimpse of what the students learned or experienced, it continues to be important to us to explore what students not only learned but what they valued in respect to the course process and content. From this perspective, we note that several students are eager to return to share their experiences with a new class. This includes volunteering to guest-speak or facilitate with the next class to share their experiences and insights. It will take more time to see the impacts of this course; however, we are hopeful that the learning will transpire into new and affirming spaces as we work toward creating healthy and socially just food system change in our communities in and outside of the classroom.

\section{Discussion and Conclusion}

It was our goal to describe the participatory process we used to develop a graduate course centered on CFS with two institutions and stakeholder participation in central Appalachia. We emphasized the way in which graduate students played an active role in designing and participating in the course as one element of our participatory praxis, and how community-university engagement and action research opportunities were pivotal to course purpose, goals, and learning activities. To do so, we provided an overview of the key concepts and ideas associated with CFS and communityuniversity collaboration, paying special attention to action research and student-led inquiry as the foundation of our participatory praxis and how that relates to CFS graduate courses such as the one we describe in this paper. We then illustrated the course-design process and focus group findings that formed the basis of our curricular experience. This included an overview of the way we used course-based action research and student-led (and graded) facilitation as central component to the courses.

We put forth that our participatory education and critical pedagogy approach reflects our participatory praxis commitment to engage student and community experience and voice. We believe course participants were able to imagine and place their own professional and personal contexts as central elements to construct what Freire (2007) refers to as a critical consciousness, which, he further argues, provides the necessary foundation for developing a transformative educational experience. For us, this consciousness is centered around food system politics and CFS.

This praxis, however, is also based on our ability to critically and deeply reflect on our own experiences and positions in the food system. To cultivate this reflection process, we strived to build a classroom environment based on understanding and transparency where food became the central cultural practice. Therefore, we suggest that a participatory praxis requires a commitment to learning with and from each other, breaking down hierarchical patterns and practices, and accepting that this learning is a politicized act. CFS is a social movement with ties to newer and more progressive movements whose goals are about unlearning the injustice that is rooted in our food system. Taking a participatory and critical pedagogy approach to the question of food access, availability, and affordability focuses our learning on the change we hope to see and continue to cultivate.

We understand that this overall approach comes with limitations and challenges when applied to a university, college, or continuing education context and developing and teaching courses. Instead of highlighting all the potential 
challenges, we chose to reflect on what might have made our FSRC course successful to emphasize the application of CFS and participatory praxis principles. First, it was fundamental that we had an existing CFS project, the AFP project in this case. The existing CFS project allowed students to engage with real-life food security challenges and the stakeholder groups working toward change in their surrounding community through the course. The CFS project offered opportunities for students to participate directly in gathering research data and learning methods and techniques with quantitative and qualitative data. Community partners were also already engaged around CFS and participating in democratic collaborations with university faculty. Students were included in these partnerships straightaway, which reduced the time required to build important relationships with the community. Further, students brought enthusiasm, new perspectives, and offered novel approaches to the activities that community participants had identified as important. Second, it was important that community stakeholders were actively involved in co-developing course activities with the students and faculty. The Stories of Community Food Work in Appalachia initiative is an example of an important product of this course that illustrates all these points. Community members described that their roles and work were important and mutually beneficial. Collaborating with the students through a creative approach helped them share their stories with a larger audience while also providing a space for students to learn community engagement and research skills. Additionally, we wish to note that a course like this requires a high level of time commitment to develop and facilitate. This may be an issue in some university or college contexts that may not historically support or advance participatory and community-engaged approaches within the classroom. We feel fortunate that our institutions and college administrations have been supportive of this course and courses like it that emphasize student-community engagement. Lastly, it was important in our course development and teaching that students be respected as active participants in their learning-as democratic partners. We sought to understand why a student would enroll in a course like this and what they really wanted to know and achieve in the course that covered both content and professional development. The focus groups and a pilot course helped us understand this in the course development process, but part of the course syllabus was intentionally left blank so those students who enrolled could collectively design and decide what was important to them. This takes a great amount of flexibility on the part of the instructor, who becomes a facilitator of learning, breaking down the power dynamics between faculty and students typical in other classes. We feel all of these components played a critical part in the success of this course and ultimately success in engaging students and building their knowledge and skills in the important area of community food security education.

$$
\begin{aligned}
& \text { Be critical, but don't be poison. Find the positive. } \\
& \qquad \begin{array}{r}
\text {-Reflection about food justice } \\
\text { from a student evaluation }
\end{array}
\end{aligned}
$$

\section{Acknowledgements}

We warmly thank participating graduate students, community partners, and Appalachian Foodshed Project colleagues for contributing their creativity, time, and energy in the development of this course experience.

\section{References}

Abi-Nader, J., Ayson, A., Harris, K., Herrera, H., Eddins, D., Habib, D.,...Villanueva, L. (2009). Whole measures for community food systems: V alues-based planning and evaluation. Retrieved from http://measuresofhealth.net/index.shtml

Allen, P. (2004). Together at the table, sustainability and sustenance in the American agrifood system. University Park: Pennsylvania State University Press.

Allen, P. (2010). Realizing justice in local food systems. Cambridge Journal of Regions, Economy and Society, 3(2), $295-308$. https://dx.doi.org/10.1093/cjres/rsq015

Alkon, A. H., \& Agyeman, J. (Eds.). (2011). Cultivating food justice: Race, class and sustainability. Cambridge, Massachusetts: MIT Press. 
Anderson, M. D., \& Cook, J. T. (1999). Community food security: Practice in need of theory? Agriculture and Human Values, 16(2), 141-150. https://dx.doi.org/10.1023/A:1007580809588

Barndt, D. (2012). Catalyzing creativity: Education and art feed the food justice movement. In M. Koç, J. Sumner, \& A. Winson (Eds.), Critical perspectives in food studies (pp. 65-88). Don Mills, Ontario, Canada: Oxford University Press.

Brown, J. (2002). A resource guide for hosting conversations that matter at the World Cafe. Retrieved from http://www.meadowlark.co/world_cafe_resource_guide.pdf

Buck, J., \& Villines, S. (2007). We the people: Consenting to a deeper democracy. Washington, D.C.: Sociocracy.info Press.

Carney, P. A., Hamada, J. L., Rdesinski, R., Sprager, L., Nichols, K. R., Liu, B. Y.,...Shannon, J. (2012). Impact of a community gardening project on vegetable intake, food security and family relationships: A community-based participatory research study. Journal of Community Health, 37(4), 874-881. https://dx.doi.org/10.1007/s10900-011$\underline{9522-z}$

Carr, W., \& Kemmis, S. (1986). Becoming critical: Education, knowledge and action research. Victoria, Australia: Deakin University Press.

Clark S., Byker, C., Niewolny, K., \& Helms, J. (2013). Framing an undergraduate minor through the civic agriculture and food systems curriculum. NACTA Journal, 57(2), 56-67. Retrieved from https://www.nactateachers.org/index.php/volume-57-num-2-june-2013/2070-framing-an-undergraduate-minorthrough-the-civic-agriculture-and-food-systems-curriculum

Cooke-Sather, A., Bovill, C., \& Felten, P. (2014). Engaging students as partners in learning and teaching: A guide for faculty. San Francisco: Jossey-Bass.

Creswell, J. W. (2009). Research design: Qualitative, quantitative, and mixed methods approaches (3rd Ed.). Thousand Oaks, California: Sage Publications.

Embry, O., Fryman, D., Habib, D., \& Abi-Nader, J. (2012). Whole measures for community food systems: Stories from the field. Retrieved from http://wholecommunities.org/wp-content/uploads/2015/12/WholeMeasuresStories-copy-2.pdf

Fisher, A. \& Gottlieb, R. (1995). Community food Security: Policies for a more sustainable food system in the context of the 1995 Farm Bill and beyond, Lewis Center for Regional Policy Studies, University of California, Los Angeles.

Freire, P. (2007). Pedagogy of the oppressed. New York: Continuum.

Galt, R. E., Clark, S. F., \& Parr, D. (2012). Engaging values in sustainable agriculture and food systems education: Toward an explicitly values-based pedagogical approach. Journal of Agriculture, Food Systems and Community Development, 2(3), 43-54. https://dx.doi.org/10.5304/jafscd.2012.023.006

Galt, R. E., Parr, D., Van Soelen, J. K., Beckett, J., Lickter, M., \& Ballard, H. (2013). Transformative food systems education in a land-grant college of agriculture: The importance of learner-centered inquiries. Agriculture and Human Values, 30(1), 129-142. https://dx.doi.org/10.1007/s10460-012-9384-8

Greenwood, D. J., \& Levin, M. (Eds.). (2007). Introduction to action researcb: Social research for social change (2nd Ed.). Thousand Oaks, California: Sage Press. https://dx.doi.org/10.4135/9781412984614

Hamm, M. W. (2009). Principles for framing a healthy food system. Journal of Hunger and Environmental Nutrition, 4(3-4), 241-250. https://dx.doi.org/10.1080/19320240903321219

Hamm, M. W., \& Bellows, A. C. (2003). Community food security and nutrition educators. Journal of Nutrition Education and Behavior, 35(1), 37-43. https://dx.doi.org/10.1016/S1499-4046(06)60325-4

Hofman, N. G., \& Rosing, H. (Eds.). (2007). Pedagogies of praxis: Course-based action research in the social sciences (1st Ed.). Bolton, Massachusetts: Anker Publishing.

Holt-Giménez, E., \& Altieri, M. A. (2013). Agroecology, food sovereignty, and the new Green Revolution. Agroecology and Sustainable Food Systems, 37(1), 90-102. http://dx.doi.org/10.1080/10440046.2012.716388

Holt-Giménez, E., Shattuck, A., Altieri, M., Herren, H., \& Gliessman, S. (2012). We already grow enough food for 10 billion people... and still can't end hunger. Journal of Sustainable Agriculture, 36(6), 595-598. https://dx.doi.org/10.1080/10440046.2012.695331

Hudd, S. S. (2003). Syllabus under construction: Involving students in the creation of class assignments. Teaching Sociology, 31(2), 195-202. https://dx.doi.org/10.2307/3211308 
Ibáñez-Carrasco, F., \& Riaño-Alcalá, P. (2011). Organizing community-based research knowledge between universities and communities: Lessons learned. Community Development Journal, 46(1), 72-88. https://dx.doi.org/10.1093/cdj/bsp041

Israel, B. A., Eng, E., Schulz, A. J., \& Parker, E. A. (Eds.). (2005). Methods in community-based participatory research for health. San Francisco: Jossey-Bass.

Jacobsen, K. L., Niewolny, K. L., Schroeder-Moreno, M. S., Van Horn, M., Harmon, A. H., Chen Fanslow, Y. H.,...Parr, D. (2012). Sustainable agriculture undergraduate degree programs: A land-grant university mission. Journal of Agriculture, Food Systems, and Community Development, 2(3), 13-26. https://dx.doi.org/10.5304/jafscd.2012.023.004

Joseph, H. (Ed.). (1997). Community food security: A guide to concept, design, and implementation. Retrieved from http://alivebynature.com/CFSguidebook1997.pdf

Julier, A. P. (2015, May). Critiquing hegemony, creating food, creating justice: Cultivating an activist food studies. Food Studies Symposium keynote at the annual meeting of the Canadian Association for Food Studies, University of Ottawa, Ontario, Canada.

Kunkler, T. (2017). What is Circle Forward? Retrieved from http://www.circleforward.us/what-is-circle-forward/

Lather, P. (1991). Getting smart: Feminist research and pedagogy with/in the postmodern. New York: Routledge.

Levkoe, C., \& Wakefield, S. (2011). The Community Food Centre: Creating space for a just, sustainable, and healthy food system. Journal of Agriculture, Food Systems and Community Development, 2(1), 249-268. https://dx.doi.org/10.5304/jafscd.2011.021.012

McCullum, C., Pelletier, D., Barr, D., \& Wilkins, J. (2002). Use of a participatory planning process as a way to build community food security. Journal of the American Dietetic Association, 102(7), 962-967. https://dx.doi.org/10.1016/S0002-8223(02)90220-8

Meek, D., \& Tarlau, R. (2016). Critical food systems education (CFSE): Educating for food sovereignty. Agroecology and Sustainable Food Systems, 40(3), 237-260. https://dx.doi.org/10.1080/21683565.2015.1130764

Minkler, M. (2000). Using participatory action research to build healthy communities. Public Health Reports, 115(2-3), 191-197. http://journals.sagepub.com/home/phr

Muhr, T. (2004). User's manual for ATLAS.ti 8.0. ATLAS.ti Scientific Software Development GmbH, Berlin.

National Research Council. (2009). Transforming agricultural education for a changing world. Washington, D.C.: The National Academies Press.

Nelson, E., \& Dodd, W. (2016). Collaborating for community food security: Emerging scholar participation in a community-university partnership. Action Research. Advance online publication. https://dx.doi.org/10.1177/1476750316656041

Niewolny, K. (2016). Stories of community food work in Appalachia: Opening space for storytelling and learning. Retrieved from http://blogs.lt.vt.edu/niewolny/

Niewolny, K. L., \& D'Adamo-Damery, P. (2016). Learning through story as political praxis: The role of narratives in community food work. In J. Sumner (Ed.), Learning, food, and sustainability: Sites for resistance and change (pp. 113-131). New York: Palgrave Macmillan.

Niewolny, K. L., Grossman, J. M., Byker, C. J., Helms, J. L., Clark, S. F., Cotton, J. A., \& Jacobsen, K. L. (2012). Sustainable agriculture education and civic engagement: The significance of community-university partnerships in the new agricultural paradigm. Journal of Agriculture Food Systems, and Community Development, 2(3), 27-42. https://dx.doi.org/10.5304/jafscd.2012.023.005

Parr, D. M., \& Trexler, C. J. (2011). Students' experiential learning and use of student farms in sustainable agriculture education. Journal of Natural Resources and Life Science Education, 40(1), 172-180. https://dx.doi.org/10.4195/jnrlse.2009.0047u

Parr, D. M., Trexler, C. J., Khanna N. R., \& Battisti, B. T. (2007). Designing sustainable agriculture education: Academics' suggestions for an undergraduate curriculum at a land grant university. Agriculture and Human Values, 24(4), 523-533. https://dx.doi.org/10.1007/s10460-007-9084-y 
Patel, R. (2009). Food sovereignty. Journal of Peasant Studies, 36(3), 663-706. https://dx.doi.org/10.1080/03066150903143079

Pothukuchi, K. (2004). Community food assessment: A first step in planning for community food security. Journal of Planning Education and Research, 23(4), 356-377. https://dx.doi.org/10.1177/0739456X04264908

Pothukuchi, K., Seidenburg, K., \& Abi-Nader, J. (2007). Building community food security: Lessons from community projects, 1999-2003. Retrieved from https://nesfp.org/cfsc-resources

Reardon, K. M. (1998). Participatory action research as service learning. New Directions for Teaching and Learning, 1998(73), 57-64. https://dx.doi.org/10.1002/tl.7307

Reason, P., \& Bradbury, H. (Eds.). (2008). The SAGE handbook of action research: Participative inquiry and practice (2nd Ed.). Thousand Oaks, California: Sage Publications.

Shafaei, A., \& Nejati, M. (2012). Does students' empowerment influence their commitment? International Journal of Education Economics and Development, 3(4), 303-315. https://dx.doi.org/10.1504/IJEED.2012.052311

Strand, K. J. (2000). Community-based research as pedagogy. Michigan Journal of Community Service Learning, 7(1), 85-96. Retrieved from http://hdl.handle.net/2027/spo.3239521.0007.110

Strand, K., Marullo, S., Cutforth, N., Stoecker, R., \& Donohue, P. (2003). Principles of best practice for communitybased research. Michigan Journal of Community Service Learning, 9(3), 5-15. Retrieved from http://hdl.handle.net/2027/spo.3239521.0009.301

Tanaka, K., \& Mooney, P. H. (2010). Public scholarship and community engagement in building food security: The case of the University of Kentucky. Rural Sociology, 75(4), 560-583. https://dx.doi.org/10.1111/j.1549-0831.2010.00029.x

Thompson, N., \& Pascal, J. (2012). Developing critically reflective practice. Reflective Practice: International and Multidisciplinary Perspectives, 13(2), 311-325. https://dx.doi.org/10.1080/14623943.2012.657795

Weber, E. (2011). Transforming higher education: Action research, learning and community politics. Africa Education Review, 8(1), 1-16. https://dx.doi.org/10.1080/18146627.2011.286138

Winne, M. (2008). Closing the food gap: Resetting the table in the land of plenty. Boston, Massachusetts: Beacon Press. 


\section{Appendix A. IRB Approved Focus Group Questions Organized by Course Design Topics}

\begin{tabular}{ll}
\hline Key Topics & Questions \\
\hline Defining Food Security & 1. How would you define the notion of food security? \\
2. & What interested you about taking a course on Community Food Security? \\
\hline Course Content & 3. What issues come to mind when you think about Community Food Security? \\
4. & Please refer to the list of topics on the second handout we provided. Given these topics \\
& related to community food security, what are the top 5 that interest you most? \\
- Food security and community food security definitions and comparisons & - Food sovereignty \\
- Multidisciplinary perspectives on food systems & - Causes of food insecurity \\
- Food security and community food security assessments \\
- Food access and health impacts \\
- Food justice (issues of gender, race, class, etc.) \\
- National policies associated with food security \\
- International policies associated with food security \\
- Interaction of sustainable agricultural production with food security \\
- Case studies of real world examples of food secure and/or food insecure communities \\
- Food assistance
\end{tabular}

Course Activities and Assessments
5. Most classes have some type of assessment to gauge student learning. What types of class activities would you find meaningful to enhance your understanding in a community food security course?

6. What are your views on using experiential learning opportunities with a community partner in a food security course? 


\section{Appendix B. Institutional Review Board (IRB)-Approved Final Course Evaluation Questions}

By completing this voluntary course evaluation, you consent to the use of your confidential and anonymous feedback to be applied to future course improvements and potential research publications about the course. Your comments will remain sealed until after final grades are entered. Each response will be held confidential at all times. Once complete, please return to your student lead for collecting. Thank you.

1. What component(s) of the course (e.g., readings, guest speakers, class discussions, site visits, student-led facilitation, narrative inquiry research project, and critical reflection statements) did you find the most valuable as a learner? Please list and explain why.

2. What course topic(s) and/or reading(s) did you find the most beneficial as it pertains to understanding food security definitions and concepts? How so?

3. What course topic(s) and/or reading(s) did you find the most useful as it pertains to applying new concepts and strategies in your professional/scholarly practice? Please explain.

4. If time permitted, what topic(s) would you recommend adding to the course (or doing more of) to best meet course learning objectives? Please explain why.

5. Overall, what would you recommend doing differently to improve the course for enhanced student learning? Briefly explain what these changes might look like and/or where they might be inserted in the syllabus.

6. As you complete your narrative research assignment, you may find yourself seeking some inspiration. What is more inspiring than a self-made t-shirt? Use the space below to "design" a t-shirt that best reflects your newly acquired understanding of "food security" or "food systems." Because space is limited, you must choose the most insightful idea, thought, or concept that most accurately illustrates this new learning. What would your t-shirt look like or say...?4

\footnotetext{
${ }^{4}$ We would like to acknowledge Dr. Arthur Wilson for the use of this question, which is derived from a course evaluation he designed and implemented at Cornell University.
} 


\section{Appendix C. Syllabus Summary by Objectives, Themes, and Assessment}

\section{Food Security \& Resilient Communities: Food Systems Theory \& Practice Virginia Tech \\ ALCE 5984 \\ Spring 2015}

Instructor:

Dr. Kim L. Niewolny

Department of Agricultural, Leadership, \& Community Education

282 Litton Reaves Hall (0343)

Tel: 540.231 .5784

Email: niewolny@vt.edu

Teaching advisors: Garland Mason \& Dr. Phil D’Adamo-Damery, Department of Agricultural, Leadership, \& Community Education; Virginia Tech

North Carolina State University AFP partners: Dr. Michelle Schroeder-Moreno \& Amanda McWhirt; Department of Crop Science

\section{Course Overview}

This graduate-level course is a critical and interdisciplinary exploration of current issues related to food security and the emerging discourse of food systems. This course will focus on the concepts of food security, community food security, food sovereignty, resiliency, and agricultural sustainability from local, regional, and international perspectives. Topics include but are not limited to: conceptual and programmatic approaches to addressing food security, food security policy, food system assessment, and the role of university-community partnerships to enhance food security and resiliency in communities. The Appalachian Foodshed Project (AFP) will provide course participants with a theoretical and practical backdrop for class discussion and coursework, including engaging with AFP scholar/practitioners and visiting the region. This course also involves collaborating with AFP colleagues at North Carolina State University. Participatory learning and asset-based community development are also relevant course themes. Graduate student standing only (3H, 3C).

\section{Learning Objectives}

Having successfully completed this course, students should be able to:

- Define, analyze, and articulate theories, practices, and policies pertaining to the emerging field of food systems

- Define and critique conceptual and programmatic definitions of and approaches to enhance food security local, regionally, and internationally.

- Define and critique scholar/ practitioner participation as change agents in the food system.

- Incorporate food system/security concepts and strategies into personal and professional practice for socially just ends. 


\section{Course Justification}

In this graduate course, students will identify, analyze and address the interconnectedness of food systems from sociopolitical, economic, ecological perspectives. We will explore the many complex and often challenging issues, as a wicked problem, related specifically to food security-what we do/don't eat and why/why not, how food is produced and distributed, and who benefits (and doesn't) from these experiences and processes. Educational and community development agendas are at the heart of this dialogue. A major component of this course is to explore the conceptual grounding and practical applications of the Appalachian Foodshed Project (AFP), a USDA-NIFA, AFRI Grant Program (Award Number: 2011-68004-30079). The AFP uses a foodshed concept to address issues of community food security in West Virginia and the Appalachian regions of North Carolina and Virginia. Through multiple levels of research, outreach, and educational efforts, the AFP aims to facilitate a network of organizations and individuals working to address issues of community development, economic viability, health, nutrition, food access, social justice, and agriculture. By working collaboratively across the region, the AFP hopes to build capacity and cultivate resilient food systems and vibrant, healthy communities.

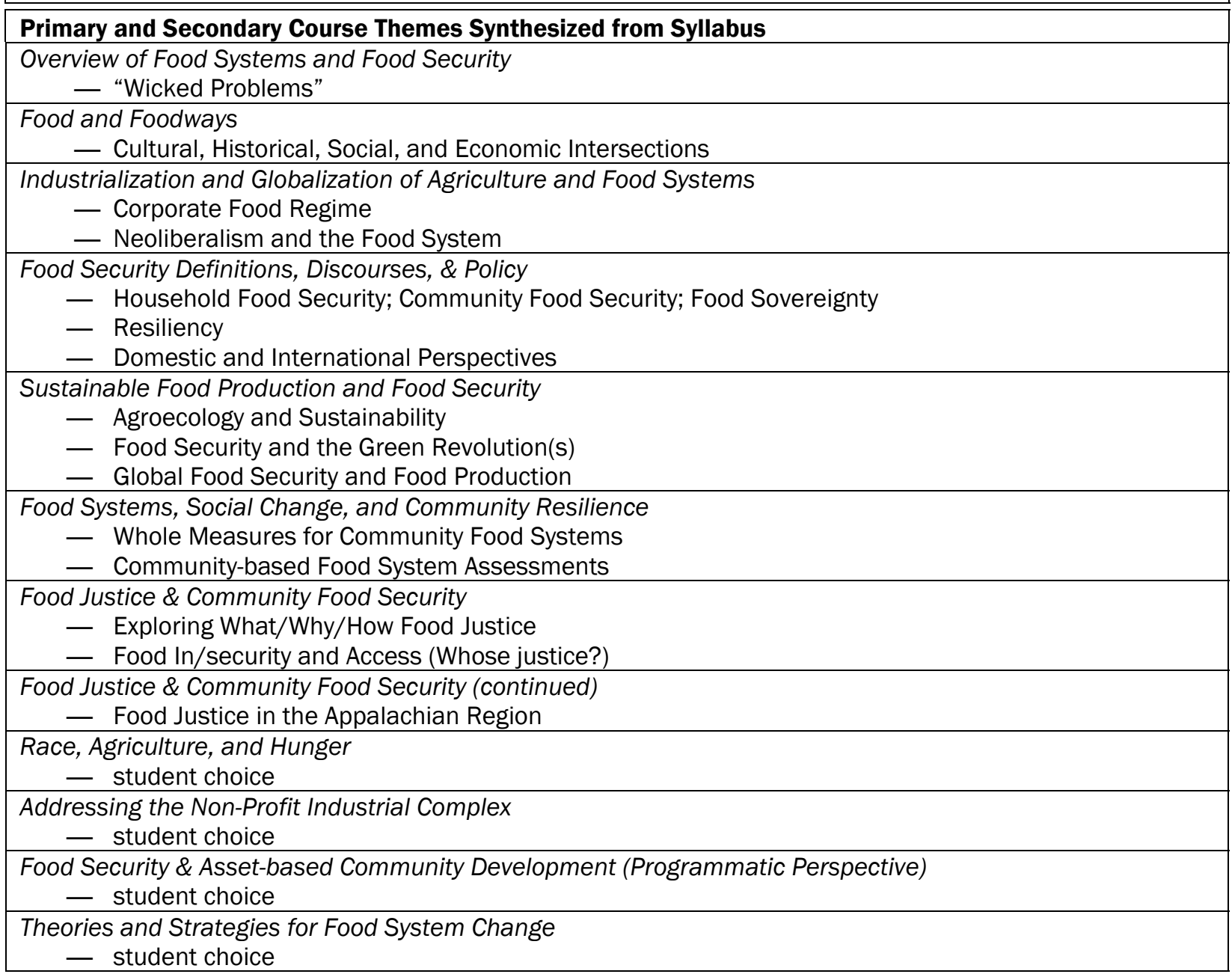




\section{Community-Engagement Activity}

Appalachian Foodshed Project Guest Speakers from Virginia and North Carolina

Narrative Inquiry Research Project with AFP Stakeholders:

"Stories of Community Food Work in Appalachia"

Visit to City Schoolyard Garden hosted by Jeanette Abi-Nader:

"A conversation about the Whole Measures for Community Food Systems"

Participation in Virginia Farm to School Conference:

"Open Space Session Facilitators"

\section{Course Assessment and Assessment Responsibility}

Weekly Critical Reflection Papers (25\%)

- Professor Assessment

Student Led-Facilitation (25\%)

- Student Self-Assessment

AFP Practitioner Narrative Inquiry Research Project (30\%)

- Practitioner \& Professor Assessment

AFP Practitioner Narrative Inquiry Research Project (30\%)

- Practitioner \& Professor Assessment 